\title{
The Significance of the Natural World in The Education of Little Tree
}

\author{
Li-Ping Chang \\ Department of Applied Foreign Languages, National Taipei College of Business, Taipei, Taiwan \\ Email: floraliping@gmail.com
}

Received 7 February 2014; revised 15 March 2014; accepted 12 April 2014

Copyright (C) 2014 by author and Scientific Research Publishing Inc. This work is licensed under the Creative Commons Attribution International License (CC BY). http://creativecommons.org/licenses/by/4.0/

(c) (i) Open Access

\begin{abstract}
Forrest Carter's The Education of Little Tree (ELT) was published as a memoir in 1976. Carter died in 1979, but his book gained in popularity, to win the American Booksellers Association Book of the Year award in 1991 and became a national best seller. The book explores the significance of nature and animals in a traditional Native American worldview, even as it espouses ecological consciousness via the education of Little Tree by his Cherokee grandparents. The Education of Little Tree has much to offer in its presentation of a Native American philosophy of life that includes caring for the earth and its creatures as well as other people, regardless of their skin color or ethnicity. This article aims to examine the ecological values portrayed by the traditional Cherokee way of life as presented in The Education of Little Tree.
\end{abstract}

\section{Keywords}

Nature, Animals, Ecological Views, Cherokee, Forrest Carter, The Education of Little Tree

\section{Introduction}

According to most traditional Native American thought, humanity is not separate from the rest of the natural world. As Chief Seattle said in the 1880s: "We are part of the earth and it is part of us. The perfumed flowers are our sisters; the deer, the horse, the great eagle, these are our brothers. The rocky crests, the dew in the meadows, the body heat of the pony, and man all belong to the same family."1 Native Americans assert that man and every creature are equal.

Forrest Carter's The Education of Little Tree (ELT) (1976) not only explores the significance of the natural world for the Cherokee, but espouses ecological awareness through the story of Little Tree, a Cherokee orphan who is raised by his Scots-Cherokee Granpa and his Cherokee Granma. Although The Education of Little Tree

${ }^{1}$ See http://www.barefootsworld.net/seattle.html 
was first published in 1976 as a memoir, it did not receive initial widespread acclaim but became popular through word of mouth, finally winning the ABBY award (American Booksellers Association Book of the Year) in 1991 and becoming a film in 1997.

In 1985, The Education of Little Tree was published by a university press as a memoir-“A True Story"about Forrest Carter's mountain upbringing by his Cherokee grandparents. But Carter was never orphaned and his Native American ancestry was distant. As Marlene Atleo states, quoted in Michelle Pagni Stewart (2002, p. 185): "Some non-Indians have written quality books about Native peoples, histories, and cultures, so it won't be argued here that only Native authors can write Native-themed stories." Henry Louis Gates states that many readers think that the novel reveals "a unique vision of Native American culture" (1991, p. 26). Jeff Roche (1999, p. 263) asserts that many critics regard The Education of Little Tree as "the Indian Huck Finn" and handles the issue of the book's authenticity by pointing out that a Native American reviewer describes the novel "as a Cherokee basket, woven out of the materials given by nature, simple and strong in its design, capable of carrying a great deal." David Bruce (2008, p. 1), on the other hand, directly confronts the problem of Asa Carter's racism: "Asa was a segregationist. Nevertheless, his book The Education of Little Tree is a work of art that is filled with humanity. Even a segregationist can be redeemed." The value of The Education of Little Tree is in its content and meaning, instead of the writer's identity.

While many critics have focused on the author's identity, few have looked at its representation of Native American ecological consciousness. This paper aims to remedy that omission and explore The Education of Little Tree from an ecological perspective, as a portrayal of a traditional Native American lifestyle and philosophy, paying special attention to the relationship between humans and the natural world.

\section{A Native American Ecology}

There are many similarities between the way Carter's characters perceive the world and the way traditional Native Americans do. Despite tribal variations, most traditional Native Americans agree about the fundamental need for humans to live in harmony with their environment. They hold an "ecological" worldview. Bill Devall and George Sessions (1985, p. 97) describe Native American philosophy in terms of the sacred Circle of Life: "In the Circle of Life every being is no more, or less, than any other. We are all Sisters and Brothers. Life is shared with the bird, bear, insects, plants, mountains, clouds, stars, sun. To be in harmony with the natural world, one must live within the cycles of life." Every living thing should harmoniously coexist in the natural world as siblings.

This ancient philosophy, and the ecological view it implies, has stimulated a contemporary reconsideration of man's relationship to the natural world. In an era when the effects of modern society's separation from (and disregard of) nature are every day more apparent in the form of global climate change, loss of species, famine, pollution of air, water, and soil, and so on, people are turning to the traditional Native American's ecological worldview as a way out of environmental disaster. Many deep ecologists stress that human society needn't go "back to the stone age" but instead can "seek inspiration from primal traditions" (Devall \& Sessions, 1985, p. 97). As J. Donald Hughes states: "It's important for us to learn from nature as the early Indians did, to keep an ear to the earth and regain our perspective by frequent experiences with the non-artificial world, with animals and wild land" (ibid., p. 98). In particular, the Native American's traditional ecological knowledge, which is a combination of "knowledge, practice and belief . . . about the relationship of living beings (including humans) with one another and with their environment" (Taylor, 2005, p. 1646) can be, as Bron Taylor suggests (ibid., p. 1648), "a source of inspiration for environmental ethics" and well worth emulating.

Native Americans have been regarded as the "sages of the conservation movement" (Cornell, 1985, p. 105), particularly in North America beginning in the 1960s, when the so-called "ecological Indians" were considered the "first ecologists, conservationists, and environmentalists" (Taylor, 2005, p. 42). The ecological Indian had "an intuitive, natural attitude toward the living world" (ibid. 43) that allowed him to live sustainably on the continent for centuries. Stewart L. Udall, a US Secretary of the Interior known for his conservation reforms in the 1960s, said: "Much of our ecology does, in fact, represent a return to the land wisdom of the Indians" (quoted in George L. Cornell, 1985, p. 105). Therefore, Native Americans set a good example in environmental preservation for modern people who can learn how to protect nature.

To see all Native Americans as the ecological sages described above may be regarded as romanticizing them, since many contemporary Native Americans either lack the special knowledge of and connection to the envi- 
ronment that was part of their traditional culture, or are destroying natural resources in the quest for jobs and money. But there are contemporary Native Americans who hold to traditional ways, and "try to live a life that is in harmony and balance with the natural order" (Weaver, 1996, p. 7). Thus, what the ecological movement is hoping to learn and incorporate is what the traditional, "ecological" Native American knew.

The traditional Native American education was one in which "the environment was the textbook and animals the teachers. The seasons became the calendar. The people's needs were the clock they worked by and their senses and imaginations were their tools of survival" (ibid., p. 7). Native Americans are educated to learn natural things via their environment. Nature guides them how to grow grains by natural law and to learn knowledge by observing animal behaviors. The earth was experienced as a nurturing mother, and the relationship of humans to earth, and to all that live on earth, including plants and animals and other human beings, was based upon the intimacy of that connection. As Native American historian Donald A. Grinde, Jr. and scholar Bruce E. Johansen (1995, p. 3) state: "Her [Mother Earth] sea water is much like our own blood. Her energy meridians are like those in our own bodies. Her soil, our flesh; her stone, our bones."

\section{A Connection to the Natural World}

The Education of Little Tree presents its ecological philosophy through the story of a five year-old orphan who goes to live with his Cherokee grandparents in the Appalachian Mountains. Through their stories and their actions, they teach Little Tree how to live in harmony with the landscape. Granma and Granpa, who are mountain people as well as Native Americans, live in the manner described by George Bird Grinnell:

The Indian's life was passed . . in close contact with nature. He drew his sustenance from the earth and from wild creatures that lived upon it. He was part of nature, and better than anything else he knew nature. A close and constantly watchful observer, nothing escaped his eye. He read the signs of the earth and the sky, and the movements of birds and animals, knew what these things meant, and governed his acts by what these signs told him. (quoted in Cornell, 1985, p. 111)

Although Granpa is illiterate, he is fluent in the signs of the natural world. For instance, crops have to be planted at specific phases of the moon and positions of the stars, but Granpa doesn't need an almanac because he can read the night sky (Carter, 2001/1976, pp. 138-139). Before he plants he also considers what kind of wind is blowing, whether the ground is too wet or too dry, and if the birds are quiet - in which case he and Little Tree are better off going fishing. While Granma suspects that this is because they prefer fishing to planting, the book makes the point that nature provides in abundance, and farming is not the only way to reap a harvest. Native American author and activist Vine Deloria, Jr. (1970) notes that the Indian "lived with his land" without destroying it (p. 186). Because this mountain land has not been destroyed, Little Tree's grandparents don't have to wait until late summer, like the white farmers do, to harvest their food. Granpa shows Little Tree how to gather food like the Indian, "from early spring, when the first greens start growing, all through the summer and fall, gathering acorns and nuts. Granpa said the woods would feed you, if you lived with the woods, instead of tearing them up" (Carter, 2001/1976, p. 103).

Granpa is so good at reading the signs of the wild animals that he keeps his hounds only to guard his corn patch, not for hunting, because he knows "the watering and feeding places, the habit and trails, even the thinking and character of all the game, far better than any hound could learn" (ibid., p. 22). He not only reads signs, he understands the wild animals who live in the mountains. Granpa can "make the deer come to him because he [knows] his curious nature; and he [can] ease through a covey of quail without stirring a wing. But he never [bothers] them, except for what he [needs]" (ibid., p. 23). Unlike the white men who kill every turkey they can catch, when Granpa traps six turkeys he and Little Tree only take three, and those are the smallest ones.

Like other Native Americans, Granpa has a "philosophy that justifies his hunting and puts it in harmony with Nature" as part of "the great circle of life" (Bruce 5). He tells Little Tree that the Cherokee "never fishes or hunts for sport, only for food" and it's "the silliest damn thing in the world to go around killing something for sport" (Carter, 2001/1976, p. 107). Since the earth is the mother of all who live on her, the animals have a familial relationship to humans: they are like brothers and sisters. Thus every creature is "sacred" and should be treated "with care and respect" (Cornell, 1985, p. 107). As Dr. Michael Fox states, the Native American belief that humans and animals are brothers and sisters makes a "philosophy of acceptance and oneness" (1976, p. 18) a crucial component of their worldview. Cherokees believed that "if they violated their sacred trust, terrible 
things would happen to them" (Perdue, 1989, p. 25). If animals are sisters and brothers, then their death so that humans may eat is a gift; to be greedy is to squander the gift, and court destruction.

\section{Animals as People}

Dawn R. Cole makes the point that Native Americans "did not worship animals; they honored and respected them. Animals were seen as teachers, guides and companions, as well as being their key to survival." 2 In The Education of Little Tree, animals fill all three roles. People are named for animals as well-Granma is Bonnie Bee, her father was Brown Hawk, a friend is 'Coon Jack - and the wild animals are also named. The hawk is Tal-con, the bee Ti-bi, the panther Pa-koh, the turkey Tel-qui. This parallel naming emphasizes the bond between humans and animals, and implies that "animals are people" (Aftandilian, 2010, p. 79).

The people who are animals in The Education of Little Tree can be family, like the dogs, or neighbors, like Ol' Slick the fox. Granpa treats the dogs with love and respect, even as he laughs at their antics; he makes sure they have work that they can do well, so that they can feel good about themselves and their contribution. Ol' Maud doesn't have a very good sense of smell but she's sharp-eyed, so Granpa has her guard his corn patch from the wild animals. Ol' Maud has another skill, and that is keeping Little Tree company in his secret place on the mountain, where she never makes a sound because she knows it is secret (Carter, 2001/1976, p. 60).

Even the dogs who are good at following a trail are only allowed to chase the fox, Ol' Slick, for fun; Granpa calls them off when the fox goes to earth in his den. Granpa and Ol' Slick have the kind of neighborly relationship that requires them to play tricks on each other. Sometimes the fox shows up in the cabin clearing, to tempt the hounds to chase him when things have got monotonous. Since this makes trouble for Granpa, who has to convince the dogs not to trail the fox, Granpa pays him back by chasing Ol' Slick when the fox is feeling "cantankerous." Far from seeming offended, that is when the fox brings out his best tricks.

The people who are animals can also be teachers and guides. Little Tree spends hours watching the struggles of a spider trying to build a web across the spring branch:

He [the spider] had determined that he was going to have the widest pearl net anywhere up and down the whole spring branch; and he picked a wide place. He would tie his cable, jump in the air and fall in the water. He'd get swept downstream, fighting for his life, crawl out on the bank and come back to that same fern. Then he'd try again. (Carter, 2001/1976, p. 57)

The spider finally solves his problem by jumping up and down on the fern until it bounces him across the spring branch, giving Little Tree a lesson in resourcefulness and determination.

As a hunter, Little Tree learns from the predators. Watching a hawk catch a quail, Little Tree feels badly for the quail, who is too slow to escape. But Grandpa tells him not to feel sad, because Tal-con the hawk has caught a slow quail, "and so the slow will raise no children who are also slow. Tal-con eats a thousand ground rats who eat the eggs of the quail. and so Tal-con lives by The Way" (ibid., p. 9). Because the hawk eats the slow quail and the rats who will eat the quail's eggs, the hawk strengthens the quail as a species. Granpa applies the same principle to human hunters: "Take only what ye need. When ye take the deer, do not take the best. Take the smaller and the slower and then the deer will grow stronger and always give you meat. Pa-koh, the panther, knows and so must ye" (ibid.).

\section{Sensing the Spirit in Nature}

As well as learning how to participate in his environment from the animals, Little Tree comes to understand the natural world by sensing it and feeling his connection with it. Granma tells Little Tree that everything in nature has a spirit. She teaches him how to feel Mother Earth through his feet: "Mon-o-lah, the earth mother, came to me through my moccasins. I could feel her push and swell here, and sway and give there...and the roots that veined her body and the life of the water-blood, deep inside her" (ibid., p. 7). Granpa takes Little Tree to the mountaintop at dawn, to watch the mountain "coming alive". As Little Tree watches and feels the mountain awakening, he realizes that he and Granpa have "an understanding that most folks [don't] know" (ibid., p. 8). As Granpa says: "Folks who laugh and say that all is known about Nature, and that Nature don't have a soul spirit, have never been in a mountain spring storm. When She's birthing spring, She gets right down to it, tearing at the mountains like a birthing woman clawing at the bed quilts" (ibid., p. 102).

\footnotetext{
${ }^{2}$ http://www.helium.com/items/1189640-totems-power-animals-wisdom-strength-symbols-emblems
} 
Granma tells Little Tree that her pa, Brown Hawk, could hear the spirits of the trees. One day Brown Hawk heard a forest of white oaks crying because they were going to be cut down to build a road. While Brown Hawk and his friends did what they could by sabotaging the road after the crew had left at night, what convinced the road builders to give up was the sacrifice of a huge white oak. Although the tree was healthy and strong, it fell across the roadbed to block construction and save the rest of the white oaks. Little Tree learns from this story why his grandparents only use "the logs that the spirit [has] left for [their] fireplace" (ibid., p. 62). He learns how to listen to the trees himself, which he can do because he lives in harmony with the earth.

When Little Tree is taken away to a Christian-run orphanage (because his grandparents are poor Indians, and because Granpa makes whiskey), he hears the trees on the mountain wailing because he is leaving. At the orphanage Little Tree sits in the corner of the yard keeping company with a solitary oak tree. "With winter coming on she had lost most of her talking leaves, but she used her naked fingers in the wind" (ibid., p. 187). Little Tree skips dinner every night to watch the Dog Star as it rises; the star and the tree bring him messages and memories of his home. Granma sends him mental images of his secret place on the mountain: "It was a little ways up the side of the mountain and hemmed in with laurel. It was not very big, a grass knoll with an old sweet gum tree bending down" (ibid., p. 58).

The tree in the orphanage yard is isolated and alone, just as Little Tree is isolated because he is an Indian, because the Reverend who runs the orphanage considers him a bastard and therefore evil (even though his parents were married by the Cherokees), and even because of his knowledge of the natural world. Little Tree is beaten severely for pointing out that the deer in a photograph are jumping on one another because they are mating. But even as his knowledge of nature has isolated him from the white Christian society of the orphanage, his connection with the natural world comes to his aid. The Dog Star and the solitary tree in the orphanage yard send Little Tree's messages "on the wind" to the trees in the mountains, and to his grandparents and their friend Willow John. Because of these messages, Willow John comes and frightens the Reverend into letting Little Tree leave. And on his return, Little Tree's secret place heals him after the long hard time away: "Through that short winter day, I lay in my secret place. And my spirit didn't hurt anymore. I was washed clean by the feeling song of the wind and the trees and the spring branch and the birds" (ibid., p. 203).

\section{A Sense of Place}

Granma tells Little Tree that she and Granpa each have a secret place in the mountains too, and that having such a place is necessary. In another story Granpa tells, Little Tree learns about the importance of the land that is their home, and what can happen to those who lose it.

Granpa and Granma employ the time-honored Native American method of oral storytelling to teach Little Tree about his Cherokee history and culture. They tell him that he has to know his people's history so that he can understand who he is in the world: "If ye don't know the past, then ye will not have a future. If ye don't know where your people have been, then ye won't know where your people are going” (ibid., p. 40). They also tell him the Cherokee version of the infamous Trail of Tears, when the U.S. government forced the Cherokees off their lands in the 1830s and 1840s. Government soldiers brought wagons and mules for the Cherokees to ride in "to the land of the setting sun", but instead of allowing the whites to pretend to be helping them relocate when they were stealing the land, the Cherokees walked. The way Little Tree hears the story, then, is that.

The wagons could not steal the soul of the Cherokee. The land was stolen from him, his home; but the Cherokee would not let the wagons steal his soul....as the Cherokee walked farther from his mountains, he began to die. His soul did not die, nor did it weaken. It was the very young and the very old and the sick....The soldiers said the wagons would carry the dead, but the Cherokee would not put his dead in the wagons. He carried them. Walking....Some of the people [watching by the side of the road] cried....And so they called it the Trail of Tears. Not because the Cherokee cried, for he did not. They called it the Trail of Tears for it sounds romantic and speaks of the sorrow of those who stood by the Trail. A death march is not romantic. (ibid., pp. 41-42)

The point is clear: although onlookers wept at their plight, the Cherokees still died. No amount of sympathy could transform into "poetry" what has been called "an act of inhumanity that took the lives of 25 percent (approximately 4,000) of the Cherokee people in the southeastern United States" (Harvey, 1991, p. 132).

Granpa's story also points out the significance of the land for Cherokees: the loss of it killed them. Like other 


\section{Native Americans:}

Their culture, spirituality, and identity are connected to the land-and not just land in a general sense but their land... when Indian tribes were forcibly removed from their homes, they were robbed of more than land. Take from the numinous landscape where every mountain and lake held meaning...Because of these intimate interrelationships, relocation was an assault upon Native culture, identity, and personhood. (Weaver, 1996, p. 12)

Along with their connection to the land they lived on, a sense of community was crucial to Native American identity. As J. Donald Hughes writes: "The traditional Indian view valued people, the interrelated social group living in harmony with nature" (Devall \& Sessions, 1985, p. 98).

\section{A Sense of Community}

Not every Cherokee went on the death march known as the Trail of Tears; some families fled deep into the mountains, living off the land as they kept moving, "silent as shadows", hiding from the soldiers (Carter, 2001/1976, p. 43). Sometimes mountain people befriended these fugitives; Granpa's Pa, who was a boy at the time, was one of them. Seeing faint signs of their presence, he left them a haunch of deer, a rifle, and later, ears of corn. Finally they came out of hiding, and showed themselves. "Grandpa's Pa "reached out his hands, and they, a dozen of them...reached out their hands and they touched. Granma said they each had to reach across a long way to do it, but they did" (ibid.). Granpa's Pa grows up to marry the youngest daughter, Red Wing; when civil war is declared he fights against the Union. The implication here is that he fights on the Confederate side not because he is pro-slavery, but because he is against the "guv'mint" and what Granpa calls "the politicians", by which he means those who want to profit from the land. Granpa's Pa doesn't "lust for land, or profit" but loves "the freedom of the mountains" like the Cherokees do (ibid.), and wants to live in harmony with the land.

Part of that harmony as presented by Granpa and Granma involves getting along with other people, irrespective of their color or ethnicity. There is a chapter in the book about Mr. Wine, the Jewish peddler, who is close friends with Little Tree and his grandparents. Mr. Wine is like kin to them because, as Granpa says, "kinfolks" used to mean "loved folks", before "people got selfish and brought it down to mean just blood relatives" (ibid., 38).

Later in the book, Granpa tells a story from his own childhood about a poor white farmer who is a Confederate soldier back from the war, his worn-out wife and two little girls, and the old black man who lives in their barn. Between them, they try to plow their land, the soldier and his wife harnessing themselves to the plow, and the old black man, who is bent in half with age, trying to guide it. Granpa is a nine year-old boy who has been raised like an Indian; as he hides in the woods watching them he sees a patrol of Union soldiers watching them as well. One of the Union soldiers brings them a mule, and then a sack of seed corn, and finally helps them plough and plant. Later another Union soldier plants apple trees all around the farm. Meanwhile Granpa, not to be outdone by Union soldiers, has been leaving the family fresh fish, because they seem so "ignorant" he's afraid they'll starve before they get their crop in.

Just when all seems well the "politicians" decide the land is worth something, so they raise taxes to move the family off their land. The Regulators end up shooting the Union sergeant when he tries to talk to them; they also kill the one-legged ex-Confederate soldier and the old black man. The politicians "passed it out that it looked like an uprising" (ibid., p. 122). A rich man buys the land, rents it to sharecroppers, and plows down the apple trees because they won't grow enough apples to make a profit.

In this story, Carter creates an idyllic world that is based not on skin color or which side of a war a person has fought on, but on people trying to get along and do the best they can for each other and the land after a horrific war. Respect and care for other people go hand in hand with a love for and care of the environment. The two Union soldiers, the one-legged Confederate farmer and his family, and the old black man, all show this love and care for the land, and kindness towards each other, despite their lack of Indian-ness. The tragedy comes from the murderous Regulators, and indirectly from "the politicians", who have no care for apple trees or other people.

\section{The Circle of Life and Death}

Early in the book, Granma tells Little Tree "everybody has two minds" (ibid., p. 19), a spirit mind that lives forever, and the body-living mind that helps you survive in this lifetime. If a person uses their body-living mind 
"to think greedy or mean", the spirit mind shrinks, and all the person is left with when they are born back is a withered spirit without understanding. If the body-living mind takes over completely, Granma tells Little Tree, you become one of the dead people, who are easy to spot because "when they looked at a woman they saw nothing but dirty; when they looked at other people they saw nothing but bad; when they looked at a tree they saw nothing but lumber and profit; never beauty" (ibid., p. 60).

In this passage Granma could be describing the Regulators and politicians in the story above, or the "Christians" at the orphanage, or the men who try to convince Granpa to sell his whiskey through them but end up lost in the mountains, in a humorous take on the same theme. Their disregard and lack of understanding of the natural world is matched by their cruelty toward other people.

Another aspect of his grandparents' spirituality is their belief that the spirit is eternal, and returns to earth after death. Death is only a chapter in the circle of life, and part of the natural order. As a poem early in the book says:

Know the death in life is here with every breaking day

That one without the other cannot be

Learn the wisdom of Mon-o-lah,

And then you'll know The Way

And touch the soul of all the Cherokee. (ibid., p. 12)

Ol' Ringer is the first friend Little Tree loses in the mountains. Ol' Ringer, an elderly dog who is partially blind, dies when he runs into a tree when he and Little Tree are escaping the government officials who are searching for Granpa's whiskey still. Ol' Ringer's death is sad but not tragic, because they sit with him until he dies, and he dies "like all good mountain hounds want to die: doing for their folks and in the woods" (ibid., p. 77). In death, Ol' Ringer becomes part of nature "under the water oak tree" (ibid., p.78).

When Willow John is dying, he lets Granpa and Little Tree know that he wants his body to fertilize an old fir-pine tree. He tells them: "When I have gone, put the body there, close to her. She has dropped many young and warmed me and sheltered me. It will be good. The food will give her two more seasons" (ibid., p. 209). Then he faces west and begins "his passing song, telling the spirits he [is] coming" (ibid., p. 210).

The people and animal friends that Little Tree loves die one after the other-Mr. Wine, Granpa, Granma, even Blue Boy, the last dog left alive, the one who accompanies Little Tree to Oklahoma, to "the [Indian] Nations, where there was no Nation" (ibid., p. 215). What Little Tree has to sustain him are the things his grandparents have taught him. Granpa had told him, when Ol' Ringer died and Little Tree said how empty he felt, that "everything you lost which you had loved give that feeling" of empty and "the only way round it was not to love anything, which was worse because you would feel empty all the time" (ibid., p. 78). Granma had told Little Tree that despite being an orphan he was lucky because he was one of those special people who had "the total love of the trees, the birds, and the waters - the rain and the wind" and would never be alone. "She said as long as I lived I could always come home to them, where other children would find their parents gone and would feel lonesome; but I wouldn't ever be" (ibid., p. 144). In the letter she leaves for Little Tree when she dies, Granma writes: "Like you feel the trees, feel for us when you are listening. We will wait for you." (ibid., p. 214). Her letter is a reminder that in his memory and in her spirit-mind she will always be with him.

\section{Conclusion}

The Education of Little Tree shows human appreciation and love to the natural world that corresponds to the traditional, "ecological" Native American philosophy. Living with his grandparents in the mountains, Little Tree becomes aware of nature with all of his senses-watching a fox or a spider, sensing the mountain as it comes alive, feeling the tree thought, and lying on the earth in his secret place. He is taught to sense his connection with Mother Earth in order to understand that he is but one of her children, so that he may live in harmony with the land, animals, and other people in his world.

Granma and Granpa teach Little Tree their values, which are based on an ecological consciousness and the Native American beliefs that everything in nature is alive, has a sacred spirit, and should be treated with respect, because, as Chief Seattle said, "All things are connected like the blood which unites one family"3. Granpa's story of the Trail of Tears makes it clear that for Native Americans, having their land stolen was tantamount to attacking the heart of their culture. Jace Weaver, talking about "the destruction of Indian lands in the service of some supposed greater public good" makes the further connection that: "Environmental destruction is simply

${ }^{3}$ See http://www.barefootsworld.net/seattle.html 
one manifestation of the colonialism and racism that have marked Indian/White relations since the arrival of Columbus in 1492" (1996, p. 3). Little Tree's grandparents practice conservation in a fundamental sense by taking no more than they need, whether they are hunting for food or gathering firewood. This respect for everything in nature extends to other people. Living in harmony with the land and other creatures means treating other people with kindness, regardless of their beliefs or skin color or human imperfections. Through his grandparents' teaching, Little Tree understands the Cherokee's history, ecological consciousness and the significance of human and animals.

\section{References}

Aftandilian, D. (2010). Animals Are People, Too: Ethical Lessons about Animals from Native American Sacred Stories. Interdisciplinary Humanities, 27, 79-98.

Bruce, D. (2008). Forrest Carter's "The Education of Little Tree”: A Discussion Guide. Athens, Ohio: The Author.

Carter, F. (2001/1976). The Education of Little Tree. Albuquerque: U of New Mexico.

Cornell, G. L. (1985). The Influence of Native Americans on Modern Conservationists. Environmental Review, 9, $104-127$. http://dx.doi.org/10.2307/3984336

Deloria, Jr., V. (1970). We Talk, You Listen: New Tribes, New Turf. New York: Macmillan.

Devall, B., \& Sessions, G. (1985). Deep Ecology. Salt Lake City, Utah: Gibbs. M. Smith.

Fox, M. (1976). Between Animal and Man: The Key to the Kingdom. New York: Coward, McCann \& Geoghegan, Inc.

Gates Jr., H. L. (1991). Authenticity, or the Lesson of Little Tree. New York Times Book Review, 24 Nov.: Sec 7, p. 1.

Grinde Jr., D. A., \& Johansen, B. E. (1995). Ecocide of Native America: Environmental Destruction of Indian Lands and Peoples. Santa Fe: Clear Light Publishers.

Harvey, K. D. (1991). Vanished Americans. Social Education, 132-133.

Perdue, T. (1989). The Cherokee. New York: Chelsea House Publishers.

Roche, J. (1999). Asa/Forrest Carter and Regional/Political Identity. In P. D. Dillard, \& R. L. Hall (Eds.), The Southern Albatross: Race and Ethnicity in the American South (pp. 235-274). Georgia: Mercer University Press.

Stewart, M. P. (2002). The Color of Their Skin? Quality Native American Children's Literature. MELUS, 27, 179-196. http://dx.doi.org/10.2307/3250607

Taylor, B. (2005). Encyclopedia of Religion and Nature. London \& New York: Continuum.

Weaver, J. (1996). Introduction. In J. Weaver (Ed.), Defending Mother Earth: Native American Perspectives on Environmental Justice (pp. 1-26). New York: Orbis. 